\title{
Isolated congenital adermatoglyphia
}

INSERM

\section{Source}

INSERM. (1999). Orphanet: an online rare disease and orphan drug data base. Isolated congenital adermatoglyphia. ORPHA:289465

Isolated congenital adermatoglyphia is a rare, genetic developmental defect during embryogenesis disorder characterized by the lack of epidermal ridges on the palms and soles, resulting in the absence of fingerprints, with no other associated manifestations. It is associated with a reduced number of sweat gland openings and reduced transpiration of palms and soles. 